\title{
Designing and providing integrated product- service systems: challenges, opportunities and solutions resulting from prescriptive approaches in two industrial companies
}

J ohannes Matschewsky, Marianna Lena Kambanou and Tomohiko Sakao

The self-archived postprint version of this journal article is available at Linköping University Institutional Repository (DiVA):

http:// urn.kb.se/ resolve?urn=urn:nbn:se:liu:diva-137904

N.B.: When citing this work, cite the original publication.

This is an electronic version of an article published in:

Matschewsky, J., Kambanou, M. L., Sakao, T., (2018), Designing and providing integrated productservice systems: challenges, opportunities and solutions resulting from prescriptive approaches in two industrial companies, International J ournal of Production Research, 56(6), 2150-2168.

https:// doi.org/ 10.1080/ 00207543.2017.1332792

Original publication available at:

https:/ doi.org/ 10.1080/00207543.2017.1332792

Copyright: Taylor \& Francis (STM, Behavioural Science and Public Health Titles)

http:// www.tandf.co.uk/journals/ default.asp 


\title{
Designing and Providing Integrated Product-Service Systems - Challenges, Opportunities and Solutions Resulting from Prescriptive Approaches in two Industrial Companies
}

Johannes Matschewsky, Marianna Lena Kambanou, Tomohiko Sakao

\begin{abstract}
Due to customer pressure and growing competition, industrial companies are increasingly moving towards providing integrated offerings of products and services (PSS). Despite this trend, literature providing a deep understanding of the challenges associated with this transition is limited, while publications discussing approaches that focus on overcoming these challenges are particularly lacking. This article is based on a multi-case study of two Swedish industrial companies undergoing the transition to designing and providing PSS. It reports on the challenges identified at the case companies as well as opportunities arising from and solutions to these challenges. Subsequently to initial research on the challenges, prescriptive approaches such as a lifecycle costing method and a PSS design method were applied in the case companies over an extended timeframe. On the one hand, these prescriptive approaches provided both a deeper understanding of the challenges, which include a persistent product centred mindset, a lack of adjustment to changed incentive structures and the separation of productand service design. On the other hand, they also led to effective solutions such as focusing on customer value and introducing a PSS transition facilitator for the design team. These solutions were adapted to the situations in the respective companies and they partly went beyond the prescriptive measures first introduced. Therefore, the article shows the applicability of prescriptive approaches and methods to detect, understand and alleviate the challenges of PSS design and provision. Further, the article provides broadly applicable learnings for industrial companies undergoing this process.
\end{abstract}

Keywords: PSS; servitisation; design method; implementation; product service integration.

\section{Introduction}

As a result of fierce competition (Manzini and Vezzoli 2003), customer demands (Oliva and Kallenberg 2003) and economic incentives (Wang et al. 2011), industrial companies that previously focused on producing and selling products are increasingly moving towards bringing integrated offerings of products and services (Product-Service Systems, PSS) to market (O'Brien 2013). Academic literature has pointed out a need for specific approaches when designing and developing PSS, as both economic as well as possible environmental benefits (Tukker 2015; Lindahl, Sundin, and Sakao 2014) can only be fully attained by jointly developing physical components and services from the earliest lifecyclestages (G. V. A. Vasantha et al. 2012; Cavalieri and Pezzotta 2012). While transitions towards PSS provision have been documented in recent research 
(Dachs et al. 2014), literature indicates that industrial companies are struggling with this process (Durugbo 2013; Martinez et al. 2010; Szwejczewski, Goffin, and Anagnostopoulos 2015).

In general, prescriptive insights, i.e. how companies should work with PSS, can be a vital support for industrial companies to carry out the transition efficiently (see Tan 2010; Blessing and Chakrabarti 2009). However, virtually all the literature describing the above-mentioned struggle is still based on descriptive studies that observe and analyse how companies do work with PSS. In contrast to this, limited literature provides results from studies of companies applying prescriptive approaches or methods, as indicated by a recent review by Baines et al. (2017). Thus, this article aims to obtain a greater understanding of real company situations and of possible ways forward by introducing prescriptive approaches adapted to the observed challenges, and thereby balancing descriptive and prescriptive aspects.

To meet this aim, the case study method was adopted to investigate two manufacturers and to answer the following research questions:

(1) What are the challenges faced by two industrial companies undergoing the transition to designing and providing PSS?

(2) What opportunities and solutions towards meeting these challenges have been identified and implemented?

(3) How can these solutions benefit other industrial actors experiencing challenges during their transition to PSS?

The answers to these research questions serve to enhance the empirically grounded body of knowledge on servitisation by providing a more advanced understanding of real world challenges and the steps taken to mitigate them.

The remainder of this article is structured as follows: Firstly, in order to provide the reader with an understanding of the state of the art in both PSS design and provision as well as prior research on challenges, opportunities and solutions in companies beginning to offer PSS, relevant literature informing and supporting the research is introduced and discussed (see Section 2). Thereafter, the case companies as well as the research methods utilized to gather and analyse data are described in an effort to provide a clear understanding and ensure the repeatability of the research performed (see Section 3). Then, the results of the empirical research are presented, first focusing on the challenges and thereafter showing the opportunities and solutions found and implemented within the two cases (see Section 4). These results are then discussed in a broader context with the aim of providing direct and applicable implications for industrial actors in the process of servitisation as well as directions for future research (see Section 5). This is followed by a summary and conclusion (see Section 6).

\section{Background and Research Motivation}

\subsection{Designing and Providing PSS in Light of Changing Incentive}

\section{Structures}

PSS are described as offerings consisting of physical components and services, 
jointly developed in order to fulfil a customer's needs (Goedkoop et al. 1999).

As industrial companies increasingly enter closer customer relationships and therefore, at least partly, change their business model, they undergo a number of changes. These changes affect the organisational structure (Windahl and Lakemond 2006; Maussang, Zwolinski, and Brissaud 2009; Cavalieri and Pezzotta 2012), the incentive structure of the business (Gebauer, Friedli, and Fleisch 2006; OECD 2015) as well as the corporate culture (Ceschin 2013; Tukker 2015).

PSS differ so profoundly from traditional product-sales offerings that a dedicated approach is required for their design (Morelli 2006; Vezzoli et al. 2015; Akasaka et al. 2012). In extending upon engineering design (see e.g. Blessing and Chakrabarti 2009), the scope of PSS design covers the joint design of both products and services with a lifecycle perspective (Mont 2002). In order to ensure effective value creation and interaction between products and services throughout the lifecycle, a high level of integration in early stages of the design process is vital (Vezzoli et al. 2015). In an effort to support industrial companies in the integration and development of product and service design, a broad set of methods and tools has been developed (see G. V. A. Vasantha et al. 2012).

Industrial companies take over increasing portions of their customers' activities as they start to offer availability- or result-oriented PSS (Meier, Roy, and Seliger 2010), resulting in a critical shift in their incentive structure. Whereas performing services and parts exchange is a source of revenue in traditional product-sales, it becomes a cost when providing a fixed price tag for a bundle of products and services (Tukker 2015; Manzini and Vezzoli 2003). Larger awareness and exploitation of this critical change in the design process is considered a success factor for PSS (Matschewsky 2017).

Concerning cost, Settanni et al. (2015) have reported that costing structures for PSS should differ from approaches used for product-sales, but they remain similar in practice. Datta and Roy (2010) have developed cost modelling techniques for availability-oriented PSS and have emphasized the dominance of production and product-cost-estimation research in academia over services and PSS provision.

As the relationship between customer and provider intensifies the deeper industrial companies venture into PSS (Grönroos and Voima 2013), the value creation for both customer and provider must be considered. Increasingly, researchers are focusing on both sides of this value creation in the design and provision of PSS (Pezzotta et al. 2014; Matschewsky et al. 2016).

\subsection{Previous Explorations of Challenges, Opportunities and Solutions for}

\section{Industrial Companies Beginning to Offer PSS}

Some researchers have explored the challenges experienced by industrial companies in servitisation. In the publications included here, particular focus is laid on those concentrating on design and provision of PSS.

In such a research effort, Martinez et al. (2010) conducted a case study within one UK manufacturing company, highlighted a number of challenges and suggested possible ways forward. Durugbo (2013) took a work-systems approach in order to explore sustainability, technology and marketability of PSS within four manufacturing companies in the UK, as well as to determine critical success 
factors. Vasantha et al. (2014) explored challenges and opportunities of servitisation in the UK laser system industry. They identified the current servitisation level and outlined potential trajectories to higher levels of integration. These remain specific to the particular industry and case. Isaksson et al. (2009) identified generic challenges and opportunities from both literature and case studies, while actual implementation efforts are not mentioned. Kurak et al. (2013) introduced a classification of challenges related to business-models, although largely without providing ways forward. Ulaga and Reinartz (2011) identified critical resources and capabilities that facilitate the PSS transition. Brax (2005) presented an in-depth case study, detailing challenges occurring during the servitisation of a manufacturer, focusing mainly on service-add-on strategy. Many of the challenges found appear to stem from this strategy, thus a higher level of early-on integration of products and services is recommended. Baines et al. (2009) have further identified different categories of servitisation challenges such as language used, value dimensions and adaptation of product design processes.

Table 1 summarizes challenges, opportunities and solutions identified in prior research.

Table 1 - Prior research on challenges, opportunities and solutions in design and provision of PSS

\begin{tabular}{|c|c|c|}
\hline Reference & Identified Challenges & $\begin{array}{l}\text { Identified Opportunities } \\
\text { \& Solutions (if applicable) }\end{array}$ \\
\hline \multirow[t]{5}{*}{ Martinez et al. (2010) } & $\begin{array}{l}\text { - Embedded product- } \\
\text { service culture } \\
\text { - Delivery of integrated } \\
\text { offerings } \\
\text { - Internal processes and } \\
\text { capabilities } \\
\text { - Strategic alignment } \\
\text { - Supplier relationships }\end{array}$ & $\begin{array}{l}\text { - Literature-based in } \\
\text { Discussion: Building service } \\
\text { culture, increased customer } \\
\text { contact, new performance } \\
\text { measurements } \\
\text { - Implemented by case- } \\
\text { company: Increased } \\
\text { customer contact, } \\
\text { employee mobility }\end{array}$ \\
\hline & - Complexity & $\begin{array}{l}\text { - Staff responsibility and } \\
\text { service buy-ins, } \\
\text { synchronised interaction }\end{array}$ \\
\hline & $\begin{array}{l}\text { - Timeliness and service- } \\
\text { tie-ins }\end{array}$ & $\begin{array}{l}\text { - Agreements controlling } \\
\text { information flow in co- } \\
\text { design situations }\end{array}$ \\
\hline & - Sustainability & $\begin{array}{l}\text { - Implementing legislation } \\
\text { - In-house advisory }\end{array}$ \\
\hline & - Ensuring customer trust & $\begin{array}{l}\text { - Customer support and } \\
\text { service mgmt. act to create } \\
\text { and retain customer loyalty }\end{array}$ \\
\hline Vasantha et al. (2014) & $\begin{array}{l}\text { - Industry-specific } \\
\text { challenges to achieve } \\
\text { higher levels of } \\
\text { servitisation } \\
\text { - Critical factors to move to } \\
\text { higher servitisation levels }\end{array}$ & $\begin{array}{l}\text { - Developing a more } \\
\text { relationship- and trust- } \\
\text { driven connection to } \\
\text { customers } \\
\text { - Reducing spatial distance } \\
\text { to key customer }\end{array}$ \\
\hline Isaksson et al. (2009) & $\begin{array}{l}\text { - Addressing customer } \\
\text { needs } \\
\text { - Modelling and simulation }\end{array}$ & $\begin{array}{l}\text { - Literature-based } \\
\text { approaches (e.g. holistic } \\
\text { customer interaction, }\end{array}$ \\
\hline
\end{tabular}




\begin{tabular}{|c|c|c|}
\hline Reference & Identified Challenges & $\begin{array}{l}\text { Identified Opportunities } \\
\text { \& Solutions (if applicable) }\end{array}$ \\
\hline & $\begin{array}{l}\text { - True collaboration } \\
\text { between service developers } \\
\text { and product developers } \\
\text { - High uncertainty through } \\
\text { extensive contract length }\end{array}$ & $\begin{array}{l}\text { learning from customer use } \\
\text { and customer involvement) }\end{array}$ \\
\hline & $\begin{array}{l}\text { - New competence } \\
\text { requirements for PSS } \\
\text { design }\end{array}$ & $\begin{array}{l}\text { - Integrated modelling of } \\
\text { products and services in } \\
\text { PSS design }\end{array}$ \\
\hline Kurak et al. (2013) & $\begin{array}{l}\text { - PSS knowledge and ease } \\
\text { of use } \\
\text { - Human resources } \\
\text { - Market segment and value } \\
\text { proposition }\end{array}$ & \\
\hline $\begin{array}{l}\text { Ulaga and Reinartz } \\
\text { (2011) }\end{array}$ & $\begin{array}{l}\text { - Service-related data } \\
\text { processing and } \\
\text { interpretation } \\
\text { - Execution risk assessment } \\
\text { and mitigation } \\
\text { - Design-to-service } \\
\text { - Sales } \\
\text { - Deployment }\end{array}$ & \\
\hline Brax (2005) & $\begin{array}{l}\text { - Marketing (changes in } \\
\text { how case company } \\
\text { marketed offering) } \\
\text { - Production (acquiring } \\
\text { necessary level of } \\
\text { knowledge) } \\
\text { - Delivery (change in } \\
\text { company culture, bad } \\
\text { timing) } \\
\text { - Product-Design (focus on } \\
\text { lifecycle vs. short-term } \\
\text { uptime and cost) } \\
\text { - Communication } \\
\text { (processes to obtain and } \\
\text { utilise feedback) } \\
\text { - Relationship (perception } \\
\text { of field staff, opportunism } \\
\text { by provider, privacy) }\end{array}$ & $\begin{array}{l}\text { - Effective information } \\
\text { management } \\
\text { - Abandoning transaction- } \\
\text { oriented systems } \\
\text { - Reducing project-focus in } \\
\text { development and provision }\end{array}$ \\
\hline Baines et al. (2009) & $\begin{array}{l}\text { - Language used with } \\
\text { service focus } \\
\text { - Communicating and } \\
\text { demonstrating value } \\
\text { through services } \\
\text { - PSS design and having a } \\
\text { focus on through-life } \\
\text { performance } \\
\text { - PSS delivery and sharing } \\
\text { resources and knowledge } \\
\text { between supply chain and } \\
\text { OEM }\end{array}$ & \\
\hline
\end{tabular}




\section{Table 1. (Continued)}

\subsection{Impact of the State-of-the-Art on the Research Conducted}

While challenges with the implementation of PSS are documented in several case studies, solutions to these challenges and the approaches used to design and implement them have been rarely reported, as also identified by Baines et al. (2017). The opportunities and solutions presented in the literature reviewed are often implicit, hard to isolate and lack structure and transferability to other industrial actors. Therefore, rather than only presenting a set of identified industrial challenges, this research is focused on distinguishing and clearly describing opportunities and solutions identified and applied within the case companies. By clarifying commonalities and differences between the case companies, the transferability and applicability of the attained results in the industry is supported. By further presenting the research results in the form of direct quotes, and through discussing these results with a strong focus on the managerial implications for industrial actors facing similar challenges, novel insights with compelling relevance for both industry and academia are sought.

\section{$3 \quad$ Research Methodology}

With the aim to broaden and deepen the knowledge on the challenges of implementing and providing integrated PSS and solutions fit to mitigate these, and in an effort to provide tangible and directly useful information to industrial actors, a case study approach was adopted in this research.

A multiple-case study (cf. Yin 2013) was conducted, in order to gain a richer understanding of offering PSS through individual but overlapping approaches at both companies. In order to structure the research and ensure its scientific validity and sound basis, the approach proposed by Eisenhardt (1989) was used as a general guideline.

\subsection{Case Selection}

The focus lies on real-world challenges experienced by industrial manufacturers when adapting their processes for designing and providing (i.e. producing, maintaining and remanufacturing) integrated PSS, and solutions resulting from the application of prescriptive approaches. The two chosen projects were conducted individually with the case companies Levor and Navitas, respectively. The efforts at Levor concentrated on more efficient PSS design and provision, based on total life cycle cost (LCC) (Sakao and Lindahl 2015) and value-capture/creation (Sakao and Lindahl 2012; Matschewsky, Sakao, and Lindahl 2015), while Navitas applied a method for PSS design that emphasized the integration of product and service aspects (Sakao et al. 2009). These prescriptive solution approaches were adapted to the company circumstances, as described in Section 4.

The opportunity of studying both companies as they underwent (and continue to undergo) their respective servitisation journeys provided a broad overview of challenges, opportunities and solutions of PSS design and provision, and is therefore key to answering the research questions. Although both cases are not directly connected, combining them has considerable advantages. On the one hand, there are notable commonalities in both case companies' initial 
circumstances in terms of the size, complexity and lifetime of the products offered that ensure a comparable point of departure. On the other hand, the different maturity of Levor and Navitas in their product-service development, the different industrial sectors they are active in (see Sections 3.1.1 and 3.1.2) as well as varying motivations and solutions approaches in the process of servitisation (see Table 2) support the industrial transferability and broad relevance of the acquired knowledge. In addition, the commonalities and differences described ensure a more comprehensive result, with data from both cases complementing oneanother. The background of both companies as multinational businesses with a history and tradition in engineering design and product sales is consistent with the companies often investigated in prior research on servitisation and PSS (see Tukker 2015) and therefore supports transferability and applicability of this knowledge in the academic realm. Table 2 illustrates initial circumstances, motivations as well as solution approaches applied at the case companies.

Table 2 - Initial circumstances, motivations and solution approaches at case companies.

\begin{tabular}{|c|c|c|c|}
\hline & Levor & Common & Navitas \\
\hline $\begin{array}{c}\text { Initial } \\
\text { Circumstances }\end{array}$ & & $\begin{array}{l}\text { - Industrial companies } \\
\text { - Globally active, } \\
\text { among the world } \\
\text { leaders in their } \\
\text { respective sector } \\
\text { - Long product- } \\
\text { oriented heritage } \\
\text { - Offer both product- } \\
\text { sales as well as PSS } \\
\text { - Opportunities to } \\
\text { improve PSS design } \\
\text { and provision }\end{array}$ & \\
\hline $\begin{array}{c}\text { Initial } \\
\text { Motivations }\end{array}$ & $\begin{array}{l}\text { - Whole lifecycle } \\
\text { perspective (cradle to } \\
\text { cradle) } \\
\text { - Analytical approach: } \\
\text { Status quo-focus } \\
\text { - Focus on cost and } \\
\text { value creation/capture }\end{array}$ & $\begin{array}{l}\text { - Adjustment to } \\
\text { changed incentives } \\
\text { when offering PSS in } \\
\text { comparison to product } \\
\text { sales } \\
\text { - Integration of } \\
\text { product and service } \\
\text { design and provision }\end{array}$ & $\begin{array}{l}\text { - Early life focus } \\
\text { - Practical approach: } \\
\text { Changes needed to } \\
\text { effectively and } \\
\text { efficiently design and } \\
\text { offer PSS } \\
\text { - Synchronise product } \\
\text { and service design } \\
\text { spatially and } \\
\text { temporally }\end{array}$ \\
\hline $\begin{array}{c}\text { Solution } \\
\text { Approaches }\end{array}$ & $\begin{array}{l}\text { - Application of } \\
\text { lifecycle costing } \\
\text { supported by PSS- } \\
\text { oriented LCC method } \\
\text { (Sakao and Lindahl } \\
\text { 2015) } \\
\text { - Assessment of value } \\
\text { creation and capture } \\
\text { based on approaches } \\
\text { (Sakao and Lindahl }\end{array}$ & $\begin{array}{l}\text { - Introducing the } \\
\text { concept of integrated } \\
\text { PSS } \\
\text { - Introducing more } \\
\text { comprehensive scope } \\
\text { of lifecycle to design } \\
\text { and provision of PSS }\end{array}$ & $\begin{array}{l}\text { - Implementation of } \\
\text { PSS design method } \\
\text { into existing processes } \\
\text { (Sakao et al. 2009) } \\
\text { - Adaptation and } \\
\text { modularisation of } \\
\text { method }\end{array}$ \\
\hline
\end{tabular}


The combination of both companies and their respective approaches allows for a broad overview of the challenges, opportunities and solutions of PSS design and provision, supporting the transferability of the acquired knowledge. ${ }^{1}$

\subsubsection{Navitas}

An industrial provider of investment machinery, providing its offerings to various large-size industrial actors on a global scale. Navitas has been a key actor in its sector for decades. In recent years, resulting from increasing customer requirements and in an effort of capturing new value-generation opportunities, Navitas has moved towards becoming a solution-provider rather than remaining solely a producer and subsequent servicer of industrial equipment. The service department of Navitas was eager to integrate service aspects into product design, which motivated the project.

\subsubsection{Levor}

A key supplier of industrial equipment for a range of customers worldwide. Levor has begun its journey towards increased value creation from service-oriented activities some decades ago. Today, availability- or use-oriented PSS represent a substantial portion of Levor's revenue and parts of the company are moving towards the provision of result-oriented PSS. Particularly with respect to its PSS offerings, Levor also conducts remanufacturing, while remanufactured units are largely utilized for short-term PSS contracts.

\subsection{Project Scope and Participants}

In the project with Levor, the main initial focus lay on understanding the changes in cost- and value perspectives associated with designing and providing PSS in contrast to selling products. Therefore, at the centre of the project lay understanding the lifecycle cost and the value-creation/capture of Levor's PSS by way of prescriptive approaches (see Table 2). Prior to this, respondents and challenges were identified through actor mapping to create a comprehensive understanding of the interconnections, interactions and information exchanges between different functions and persons involved in the design and provision of PSS. Naturally, through the exploratory nature of this approach, data was gathered

\footnotetext{
${ }^{1}$ Due to requirements of confidentiality, the authors had to ensure that both companies cannot be identified based on the information given. Therefore, aliases are used instead of actual company names, and some remarks by participants of the study were generalized to ensure anonymity. Regardless, the authors took utmost care to deliver an accurate and precise representation of the situation at Levor and Navitas as a basis for the creation of broadly applicable knowledge for academia and practice alike.
} 
in various company departments and with a very broad set of respondents.

With Navitas, the focus lay on the testing and evaluation of a PSS design method for implementation into the existing, product-centric design processes (see Table 2). Towards the end of the project, a number of focus group meetings were held, where challenges that went beyond the implementation of a PSS design method emerged. This resulted in a focus shift in the project, towards the challenges of mastering servitisation.

Table 3 provides information on the projects, respondents and data gathering efforts in the studies conducted.

Table 3 - Respondents and approaches in data gathering efforts.

\begin{tabular}{|c|c|c|c|c|}
\hline & \multicolumn{2}{|c|}{ Levor } & \multicolumn{2}{|c|}{ Navitas } \\
\hline $\begin{array}{l}\text { Project } \\
\text { timeframe }\end{array}$ & \multicolumn{2}{|l|}{ Since 2014} & \multicolumn{2}{|l|}{$2012-2015$} \\
\hline $\begin{array}{l}\text { Functions of } \\
\text { respondents }\end{array}$ & \multicolumn{2}{|c|}{$\begin{array}{l}\text { Product Development (e.g. R\&D } \\
\text { Coordinator; Project leader; Project } \\
\text { Manager; Group Leader; } \\
\text { Mechanical Designer;), Service (e.g. } \\
\text { Service Leader; Service } \\
\text { Coordinator), PSS Management } \\
\text { (e.g. Senior Manager, Manager), } \\
\text { Product Management (Product } \\
\text { Group Manager, Product Manager), } \\
\text { Sales Management (e.g. Salesman, } \\
\text { Key Account Manager), Accounting }\end{array}$} & \multicolumn{2}{|c|}{$\begin{array}{l}\text { Product Development (e.g. } \\
\text { Development Project Lead; } \\
\text { Manager Product } \\
\text { Development), Service (e.g. } \\
\text { Team Leader Service; Service } \\
\text { Design Engineer; Service } \\
\text { Manager), Management (e.g. } \\
\text { Director, Product } \\
\text { Development Management; } \\
\text { Director Product } \\
\text { Development; Manager R\&D } \\
\text { Service; Manager Service } \\
\text { Development ) }\end{array}$} \\
\hline \multirow{3}{*}{ Data gathering } & Actor mapping & $\begin{array}{l}5 \text { sessions, } 90 \\
\text { minutes each }\end{array}$ & Document study & \\
\hline & Focus Group & 1 & Focus Group & 4 \\
\hline & $\begin{array}{l}\text { Expert } \\
\text { Interview }\end{array}$ & 22 & $\begin{array}{l}\text { Expert } \\
\text { Interview }\end{array}$ & 2 \\
\hline
\end{tabular}

\subsection{Data Gathering and Analysis}

As shown in Table 3, within both projects, data was collected over an extensive period of time and from a broad set of respondents. In the following section, each type of method for gathering and analysing data is described.

\subsubsection{Interviews}

Interviews were one of the main data-gathering approaches used. In most cases, these were semi-structured interviews (Flick 2009; Miles, Huberman, and Saldaña 2013). Interview-guides were often used, although particularly in the project with Navitas, relevant information was given in entirely different contexts and can be seen as results of side-tracks going beyond the intended scope of the semi- 
structured expert interview (Flick, 2009, 156). All interviews were recorded digitally.

\subsubsection{Focus Groups}

A focus group generally consists of 6-10 participants (Patton 2002, 385), a requirement which was observed on all the occasions this data-gathering method was employed. Particularly in the interest of cost and time-effectiveness (Krueger and Casey 2014, 5), focus groups were utilised, albeit possibly at the cost of silenced minority perspectives or lacking confidentiality (Patton 2002, 387). The focus group sessions commenced with a brief discussion topic presentation from one of the authors. A major advantage of using focus groups was that a number of participants with different functions and backgrounds were brought into one room to discuss a common topic from different angles (see Patton 2002, 385ff.).

\subsubsection{Data Analysis and Compilation}

All data-gathering efforts were recorded and stored digitally. For all focus group sessions with Levor and Navitas, summaries and minutes were written directly after the meetings and subsequently approved by company representatives. The recordings from the data gathering were selectively transcribed (Flick 2009). Through pattern matching with prior knowledge as well as cross case synthesis (Yin 2013), patterns emerged, and the identified statements were recorded by way of open coding, largely relying on naming through analyst-terms (Strauss and Corbin 1998; Glaser and Strauss 2009). The resulting transcribed and coded quotes were entered into a table and through multiple sessions held by the first and second author, the quotes were again clustered (Miles, Huberman, and Saldaña 2013) into categories through comparative analysis (Strauss and Corbin 1998). These categories constitute the challenges, opportunities and partly solutions for Levor and Navitas. Naturally, this approach may suffer from some bias (Flick 2009). To increase the accuracy of the data analysis, the categorised results and inductions were returned to key practitioners at Levor and Navitas for checking and possible corrections. This was also done to ensure transferability and a high level of usability of the results of this research for industrial professionals.

\subsection{Prescriptive Approaches}

A number of prescriptive approaches were introduced and applied within Levor and Navitas. This subsection presents these methods briefly and illustrates their relevance to the research results, while general lessons learned with respect to prescriptive approaches applicable in industry are discussed in Section 5.

\subsubsection{Actor and Interaction Mapping}

Actor mapping was used to support expert interviews focused on understanding internal relationships within companies. Respondents at Levor were asked to elaborate upon their work, interactions and flows of information with regards to 
other actors in the company and the way they work with integrated offerings. A whiteboard was used to map this information, using different colours to structure the gathering of data. Actor mapping has been applied in different companies in prior research (Lindahl, Sakao, and Carlsson 2014; Desai, Lindahl, and Widgren 2016) and is used as both a research method and internally by Levor.

\subsubsection{Value Evaluation for PSS}

With a focus on value, both a customer-focused (Sakao and Lindahl 2012) and indepth provider-focused (Matschewsky, Sakao, and Lindahl 2015) value-evaluation method were applied at Levor. The goal of these methods is to establish a connection between individual product- and service-components and the expected value creation and -capture throughout the lifecycle of an integrated offering already during the design process. Further, both methods facilitate the learning and deepened understanding of employees with respect to lifecycle-oriented value creation in PSS and formed the basis of the value-related results attained.

\subsubsection{Lifecycle Costing (LCC)}

LCC (see Rebitzer and Hunkeler 2003) was applied at Levor in order to create an understanding of the actual cost of Levor's offerings throughout the lifecycle. The methodical approach used (see Sakao and Lindahl 2015) was the basis for the attained results with respect to costing and data handling, and continues to play a key role in informing and guiding the servitisation process at Levor. The method applied in this case is particularly focused on the improvement of PSS offerings based on lessons learned from the application of LCC.

\subsubsection{PSS Design Method SPIPS}

A comprehensive customer-focused PSS design method (Sakao et al. 2009) centred around Quality Function Deployment (QFD) was tested and applied at Navitas. The method aims to support the adaptation of design processes for an integrative product- and service design and constitutes the foundation of the results attained at Navitas.

\section{$4 \quad$ Results}

\subsection{Understanding Challenges for Industrial Companies in Servitisation}

\subsubsection{Persisting Product-Centred Mindset}

Service aspects are traditionally not addressed very well in a technologyproject. (Service Manager, Navitas)

Both companies (including management) displayed a strong and persistent 
product centred mindset that proved to be an obstacle in capturing the full efficiency and effectiveness of integrated product-service offerings. Considering that both case companies have a multi-decade history in designing and providing technologically advanced products, the associated prevailing mindset was summed up by an interviewee as follows:

I would say that tradition is probably the main reason why it looks like this, because it has been about selling products, it has been about developing products. Now we know that it is changing [...] [availability-oriented PSS] are a very important business for us [...] I don't think we talk enough about it so I would say that we do need to spend a lot more resources and time to change that way of thinking. (R\&D Strategic Advisor \& Team Leader, Levor)

This focus on the product as well as on technological considerations and the lack of integration was observed at the company levels as well as in the departments participating in the projects, as all participants made clear reference to or displayed this mindset, thus also signalling an underlying organisational culture.

[A barrier to integrating the design of products and services in an early stage of the lifecycle is the] mindset of engineering, $R \& D$ and product management. [The] shift of focus from technology to customer feels threatening. (Team Leader Service, Navitas)

We are thinking a lot about the product today and the service organization that is helping us get service requirements are thinking product. It is not only $R \& D$ that needs to change but many different departments within the company. (R\&D Strategic Advisor \& Team Leader, Levor) [Navitas] is an engineering company. All of our products are overdesigned, over-engineered. It's obvious, everyone knows about it. (Manager Service Development, Navitas)

What was not said during interviews was equally revealing. For example, when a group product manager at Levor was asked about what information was used for assessing the need for a new offering, the answer, which lasted two and half minutes focused on product-related information. When prompted by the interviewer, the respondent elaborated on customer value and service as well.

The question of mindset is largely an individual one, and there appear to be notable differences between the respondents of this study. However, because individuals are the ones initiating and implementing change, mindset can create substantial barriers at all stages of a change process, the last previous quote is a pertinent example of mindset opposing structure.

Ultimately, the testing and adaptation of the prescriptive PSS design method revealed a lack of readiness in individuals at Navitas to use the method in their daily work - the solution presented in Section 4.2.4 directly corresponds to this challenge. This is generally understandable, as servitisation can be an overwhelming change for a product-oriented organization and therefore could be a high risk for its management to take. 
The question of product- and service-design separation goes beyond the individual to encompass organizational challenges at the design stage.

The product and service components of a PSS offering should be designed simultaneously and should fit each other in the same way that modules of a single product should fit together. According to interviewees there exists a temporal, organisational and structural separation between product and service design.

The temporal and organisational separation leads to unwanted lock-in effects and sub-optimization of the different parts. The product, which is designed first, limits the way the service can be designed.

[...] you start with the [physical offering], [...] and then, the other things come down the line. (Development Project Lead, Navitas)

What is important is to integrate. Not to consider the demands from the [product development] unit in one way and those from [service development] in another. We have to combine them, and this is what we are not doing here. We are only in parallel, not together. And once we come together, it is already too late. The concept is already in place. (Manager Service Development, Navitas)

They [Product Development] hamper us. (Service Design Engineer, Navitas)

The organisational separation also means that information is not capitalized upon. For example, while conducting LCC at Levor, it was clear that the vast majority of service related cost data and subsequent knowledge remained within the service management division.

We have a lot of islands with huge knowledge and competence, but these islands are not connected to each other. (Manager Service Development, Navitas)

The structural separation becomes apparent when considering the size of the respective product and service design teams, the expertise of the people involved and the channels of communication. The structure is not only separate but heavily focused on the product. The actor mapping approach used to document the way service requirements were collected and used in Levor for the development of new projects highlighted this difference. Even more so, the separation of product and service design became apparent when discussing a recently finished four-year development project at Navitas:

We bring in somebody from service [to product development], but we don't really care what he does. And we know he has a lot of tools that he needs, to do his service, and we know they cost a lot of money, and that's terrible! The organization contributes [to the fact] that we [are] split like this. The topmanagement would like to see: How much profit is there in the new sales? How much profits is from the service? So that it shouldn't be too much mixed. That gives a lack of contact. And at the same time, it leads to conflict, because everyone needs to improve the [respective] profit. (Manager Product

Development, Navitas) 


\subsubsection{Alignment with Changing Incentive Structures}

The provision of integrated product service offerings inevitably changes the company's incentive structures. For example, sources of revenue, cost, customer and provider value and their dispersion over time change. Aligning the departments of the company to these changes in incentives is not only of paramount importance to profitability but also proved to be a challenging experience for Levor and Navitas.

If, when transitioning to PSS, the offering remains in the possession of the provider, service and maintenance, once a source of income, now become a cost. This is a challenge for the service, sales and $R \& D$ departments respectively:

When I ask [the service technicians] who earns money on spare parts in our [availability-oriented PSS] offering, then everyone answers: "It is the department of spare parts." and I say "No, it is our suppliers, every spare part we replace is a cost for us!" The salespeople haven't understood this either. (Manager Business Solutions, Levor)

Do you know who every salesman's best friend is? "Bill Spare-parts". They still don't get that it is a cost for us. (PSS \& Leasing Manager, Levor)

Even on management-level, understanding this incentive-change remains a challenge:

I see a few things that we've done when I was at [development department]. Design to [first] cost, that in the end run were probably more expensive to the customer. Let's say, having more time at site. Let's say not having a [component] as part of the package, it's going to cost the customer more time at site, while lowering overall first cost for sales. (Director Product Development, Navitas)

Because revenue is not incurred just at the time of sale but is dispersed over the lifecycle, there is a new incentive to prolong life. Levor has seen that remanufacturing and entering the second hand market is profitable but this has yet to manifest itself as requirements in the design and development stage. This became particularly clear during the actor mapping workshops conducted with Levor practitioners.

Generally, one can say that we have no contact to [the remanufacturing department]. What [information] we get, we get from [aftermarket division]. But there is no focus on renovation and re-use, rather maintenance and service. (Project Manager Design, Levor)

We do not have any communication at all between [design and development division] and the [remanufacturing department]. I spoke to colleagues in the [service department], even they have very little communication. We hardly take remanufacturing into account in the design process. (Product Designer, Levor)

\subsubsection{Prevalence of Product-Focused Information and Costing Structures}

Although it is known that incentives structures change, measuring these changes 
can be a substantial challenge, because structures are not in place to collect highquality information about the offering and its associated costs across the lifecycle. Knowledge about the costs and the subsequent models are also needed in order to motivate the transition to a servitised environment. As stated by an interviewee:

[...] We don't have a very good model for saying: Perhaps it is worth making a part a little bit more robust and a more expensive design because from a lifecycle cost it will be more beneficial. [...] For product cost we have a very clear model and it is very easy to make a decision from that [...]. You need to show the money to make the change, you can't say it feels like it is better to do it this way. (R\&D Strategic Advisor \& Team Leader, Levor).

Although digitalisation is progressing, there are still a number of reasons why good quality data is not readily available. In the words of the respondents themselves:

Information is in a lot of silos. (Group Product Manager, Levor)

Alternatively, data has not been gathered because traditionally, the provider collected information on production costs and did not concern itself about operational and through-life costs such as repair and maintenance as well as end-of-life costs, which were covered by the customer.

What we know about service market costs is based on what we invoice. (Project Manager Service Market, Levor)

Furthermore, data itself is only of value if knowledge can be distilled from it, establishing data analytics is an issue for manufacturers.

[...] The challenge is, it's so much information (from the sensors on the product) and you have to find a good way how to analyse it and make reports and find the value in it. (R\&D Strategic Advisor \& Team Leader, Levor)

Finally, apart from the concerns about quality, most of the data described concerns only the product. Even the often lacking operational information is product-focused. But in order to successfully design an integrated offering, more complex data concerning the customer and the generated value needs to be collected. This is exemplified in the following comment:

For the same contract, for the same customer, for the same type of product at two sites with a similar environment, the profits can differ greatly. Firstly because of the [state of] product itself, secondly because of how the service technician behaves and thirdly because of how the person operating it behaves, this information isn't collected anywhere and doesn't show in our cost models and it is very hard to put this in money. (Senior Manager Business Solutions, Levor)

During the extensive efforts associated with carrying out a prescriptive lifecycle costing approach, the lack of data handling systems as well as the lack of 
systematic data-gathering became obvious and was a starting point for internal improvements and changes in that regard.

\subsection{Opportunities and Solutions to the Challenges of Servitisation}

The opportunities and solutions that are addressed in this section were identified and implemented at the companies. Some are directly related to the prescriptive approaches brought in during the projects, while others arose indirectly as a result of the increased understanding triggered by working with the concept of PSS and the suggested approaches over an extended period of time.

\subsubsection{PSS Design Methods - A Guiding Light for the Integration of Product-}

Service Design

There is a substantial quantity of literature introducing (e.g. Pezzotta et al. 2016; Lim et al. 2012) and discussing (Matschewsky, Lindahl, and Sakao 2015; G. V. A. Vasantha et al. 2012) design methods for PSS. In the case of Navitas, the presence and use of a PSS design method during a first evaluation of product-service integration both during design and provision of PSS can be seen as a key support to uncover and solve challenges that can emerge.

The depth and direction of the challenges and opportunities identified is of course determined by the focus of the method itself. In this case, a clear focus on the creation of customer value and life-cycle considerations is present. As a result, these issues continuously re-emerged during the discussions held.

We [Service Design] are focused on lifecycle cost, and you [Product Design] are more focused on first cost. There is a discrepancy there, so I would assume that this method could help in that sense, to implement more the lifecycle perspective. (Manager R\&D Service, Navitas)

The cross-disciplinary focus of the PSS design approach used, here exemplified through customer-focused QFD workshops, led to a much more structured understanding of current and possible future collaboration and integration between product- and service design divisions. The status quo was described as follows:

I mean, you start with the [physical offering], [...], and then, the other things come down the line. (Development Project Lead [Navitas Offering]) I believe that this kind of [method] approach will shield us from the "engineering approach". (Manager Service Development, Navitas)

The importance of a structured design method to guide and inform the service transition and integration process as well as to help quantify new emerging value dimensions was summarized as follows:

It [Integrated Product-Service Design Method] should be part of our [ServiceDesign] process, plus [Product-Design Division] process, [so] that we will consider these aspects together. That we will take a look on customer benefits, 
but don't forget our own benefits as well. (Manager Service Development, Navitas)

And then we need to define these project quite on an [early phase] level.

(Development Project Lead [Navitas Offering])

Correct. And then we will go into the project. [...]

\subsubsection{Understanding Cost - Providing an Understanding for PSS in the Language of Money}

In both Levor and Navitas, efforts towards understanding the true cost of offering PSS by way of a prescriptive approach proved to be a key step in the journey towards better PSS design. In Levor, developing a life-cycle-cost-perspective was seen as important to move the service transition forward, particularly as a strong focus on first cost currently remains:

And if there is a good understanding of the total life cycle cost, [...] it could be worth spending some extra money in the development phase so that we know we get the money back in reduced maintenance. (Product Group Manager, Levor)

Further, the necessary integration of budgets currently split along divisionlines and lifecycle stages, became an ongoing focus at Navitas:

This is a matter of integrating budgets. It's not this [product] budget and this [service] budget, it's a mix! (Development Project Lead [Navitas Offering])

Levor has benefitted from the presence of a prescriptive, lifecycle cost focused approach in its efforts of assessing the actual internal cost of its availability/use-oriented PSS offerings. The need for this is explained by a Levor employee:

Both the benefit [value] side and the cost side are changed with [availabilityoriented PSS]. What we invest in our solutions is much more important with [PSS] since we take more responsibility from a lifecycle perspective. (R\&D Leader, Levor)

\subsubsection{Value - Long-Term Thinking on the Cost-Side}

As their activities have extended throughout most of the lifecycle, Levor and Navitas have come to understand how accessing and identifying value can help with focusing on efficiency throughout all of the lifecycle stages.

We must ask ourselves: What is it we actually do? [The concept of] Value impacts almost everything one does with a focus on efficiency! (R\&D Leader, Levor)

Again supported by a prescriptive approach, Levor is keen on understanding the value perceived and attained by its own employees and its 
customers throughout the lifecycle, with the goal of designing and providing its offerings in a fashion that is concentrated on generating and capturing this value.

To accelerate the shift towards solutions, we need assessment tools that we can trust, that can show that e.g. over-dimensioning [in the design process] can at times be economically viable. (R\&D Leader, Levor)

The applicability of value-assessment methods is still under evaluation at Levor. At Navitas, the value-focus is only just emerging.

Here the idea is to use this tool [Integrated Product Service Design Method] in order to evaluate, quantitative, not only qualitative evaluation, what could be the priority for this [development project]: What is this projects contribution to customer value, and to [Navitas'] value? (Manager Service Development, Navitas)

\subsubsection{A PSS Facilitator - Lessons from a Challenging Attempt at Product Service Design Integration}

The challenges of moving towards design and provision of PSS at Navitas became apparent towards the end of the project evaluating a prescriptive product-service design method. The main reason for this can be attributed to the project's design. The evaluation and testing of the method was carried out with individuals and groups of individuals as they cooperate in daily business today. Although there was some knowledge particularly about the temporal separation between productand service design in Navitas' processes, the extent of the separation only became apparent through the cross-disciplinary meetings held towards the end of the project.

Driven by the service organisation, management created a director-position in charge of organising increased cooperation between product- and service design, with the aim of achieving a higher level of integration throughout the process: A PSS Facilitator. This development is illustrated by the following statement of the driving person behind the initial research project and the appointment of the PSS Facilitator:

[Product development] unit and service still sit in separate kingdoms, and you [to product development managers and engineers] develop under the assumption that everyone knows about what you are doing. In service, we develop, and then we realize, that we need a new technology, and we don't realize, that something is already developed by your [product development] staff. So this is why we need to work very closely together. (Manager Service Development, Navitas)

This was also reiterated by practitioners in the product-design division. When discussing the amount of PSS contracts which were to be expected when bringing a new, currently-developed offering to market:

Then of course there are different strategies we need to have for the product; and how is that discussed when we start a new project? What strategy should we have for this particular product? Is it service-to-cost or is it service 
contracts? I mean, things like that are not visible today either. So I think clearly an interaction between service [design] and [product] development is key at a point like this, and I think the interaction between us [must be] intensified. It's a mutual interest and a mutual responsibility. (R\&D Manager, Navitas)

Particularly due to the substantial disagreements at Navitas between product- and service design as to what changes are necessary, such an integrative position to start the process proved useful to initiate a process that would otherwise be deemed controversial and, above all, a challenge to fund.

\subsubsection{Grasping the Status Quo - Actor Mapping in Design and Provision of PSS}

When aiming to become more systematic in offering PSS, Levor was challenged by the lack in overview over its design and provision processes. As it became clear, organisational charts only tell parts of the story and are often insufficient. An effort was made to build an understanding of relevant actors and both formal and informal communication- and interaction-pathways among them. Here, e.g. lacking feedback mechanisms from remanufacturing were identified during the mappingworkshops. This circumstance was particularly remarkable considering the importance of remanufactured units:

My perspective is that first life [is] interesting but really it's the second life where we can make money, where all the money comes in: [Remanufactured offerings] sold or as short-term [PSS offerings]. (Senior Manager Business Solutions, Levor)

Overall, this exercise provides the basis for a more focused assessment of needed changes and developments to move towards a more efficient design and provision of PSS.

\subsubsection{Customer Centric, Business Driven Design and Provision of PSS Instead of a Focus on Product and Service}

At both Levor and Navitas, efforts became discernible to overcome the challenge of product-focused thinking and the separation of product and service throughout the life of the offering. Instead of picking hard fights on the old turf, progressive practitioners at both companies just moved to a new playing field. In this, many of the solutions and efforts above are subsumed:

The big success will come when it [development process] will be driven from the business point of view. Then we will get the support and understanding from everyone. [...] That way, it's customer driven, market driven, rather than engineering driven. (Manager Service Development, Navitas)

Increasingly, the impact of servitisation on the companies and their future business is understood by the practitioners. They view a successful transformation 
as a vital precondition for the continued prosperity and success of their companies:

I really believe that we will move more and more towards [offering PSS], and we will at some point stop selling [Levor offerings], except for some basic [models]. Particularly since we see ourselves as a premium-provider will focus on increased integration in order to continue growing. [...] Right now there is a tension between product designers focusing on values critical for traditional sales, and the increasing volume of [PSS offerings]. This will shift to design for solutions, because customers require it. (R\&D Leader, Levor)

\section{$5 \quad$ Lessons Learned - Focus points for Industrial Companies in Servitisation}

\subsection{Challenges, Opportunities and Solutions}

Over an extended period of time, challenges were identified at the case companies. Prescriptive solution approaches were applied to mitigate these challenges, while further challenges arose from the implementation and testing of these approaches. Thus, an iterative spiral of challenges, opportunities and prescriptive but adaptable approaches emerged.

When analysing the challenges identified and presented above, it is clear that they often reinforce or extend knowledge found in prior research. The challenges associated with a persisting product centred mindset have been seen also by Martinez et al. (2010). During the studies conducted, differences in the adjustment to new approaches between different internal organisations became apparent. This underlines the assertion of Windahl and Lakemond (2006), who recommend implementing PSS first in a separate internal organisation, which may lead to a new, forward thinking mindset and is reflected by the apparent shift to new paradigms as detailed in Section 4.2.6.

Similarly, having an integrative position as a facilitator for the integration of product-service design and provision resounds findings on organisational restructuring (Durugbo 2013) as well as on the necessity of management support (Song et al. 2014; Brax 2005; Tan 2010). The separation of product and service design in a spatial, temporal and organisational sense that was identified in the course of the study reinforces and extends the assumption of challenges caused by varying skillsets of product- and service designers (Elfving and Urquhart 2013), and is indicated by other researchers (e.g. Oliva and Kallenberg, 2003; Tan, 2010). The identified challenges therefore provide additional depth to the inherent assumptions about product-service integration and showcase how divided these organisational units can be. This is especially true in the case of Navitas (Section 4.2). The integrative capabilities of prescriptive PSS design methods have been discussed in prior research (Matschewsky, Lindahl, and Sakao 2015; Cavalieri and Pezzotta 2012), however, the results presented here illustrate and substantiate the industrial understanding and the need for prescriptive approaches as solutionsupport for facilitators to meet the challenges industrial companies face. The extent of the challenges resulting from a changed incentive structure when transforming to become a PSS provider showcases the long term changes required 
to reap the benefits of a stronger focus on service (Brax 2005). By discussing challenges experienced by industry actors and providing a structured approach towards solving them, the identified results with regards to a persisting productorientation and with respect to information handling and costing not only reinforce but also extend the relevance of earlier research (Settanni et al. 2015; Brax 2005; Durugbo 2013).

In contrast to some issues identified in prior descriptive research, the prescriptive approaches applied here did not bring to light challenges with regards to service delivery or contracting. This may be due to the nature of the approaches and the respondents, although representatives from many company divisions involved in PSS design and provision provided their insight.

\subsection{Practical Implications - Learnings for External Companies}

In order to condense the attained knowledge and to make it available to non-academic actors, Table 4 shows possible courses of action intended to facilitate the efficient design and provision PSS. Due to the challenges of overly complex or simplistic models of development, only an estimation of the appropriate time-frame for the implementation in relation to maturity (see Pigosso and McAloone 2016) is given. The recommended approaches and expected outcomes are exclusively based on lessons learned at Levor and Navitas and feedback given by practitioners in the course of both projects.

Table 4 - Managerial implications of the studies' findings.

\begin{tabular}{|c|c|c|c|}
\hline $\begin{array}{l}\text { What? (Course } \\
\text { of action) }\end{array}$ & $\begin{array}{l}\text { When? (What } \\
\text { level of PSS } \\
\text { maturity) }\end{array}$ & $\begin{array}{c}\text { How? (Approach, supporting } \\
\text { tools) }\end{array}$ & $\begin{array}{l}\text { Expected } \\
\text { outcome }\end{array}$ \\
\hline $\begin{array}{l}\text { Systematically } \\
\text { take account of } \\
\text { the } \\
\text { organisational } \\
\text { status quo in } \\
\text { order to make } \\
\text { informed and } \\
\text { goal-oriented } \\
\text { decisions as to } \\
\text { what changes } \\
\text { are appropriate }\end{array}$ & $\begin{array}{l}\text { Ideally when } \\
\text { planning to } \\
\text { initially offer } \\
\text { PSS, but at any } \\
\text { later point when } \\
\text { intent on } \\
\text { changing } \\
\text { approaches, } \\
\text { structures or } \\
\text { methods to } \\
\text { become better } \\
\text { at providing PSS }\end{array}$ & $\begin{array}{l}\text { - Depending on company size and } \\
\text { complexity } \\
\text { - Discussions to achieve a deeper } \\
\text { understanding for actual existing } \\
\text { collaboration and lacking } \\
\text { information flows, e.g. led by PSS } \\
\text { Facilitator (see below) } \\
\text { - Can be supported by a } \\
\text { systematic approach such as actor } \\
\text { mapping (see Durugbo, Tiwari, } \\
\text { and Alcock 2013) }\end{array}$ & $\begin{array}{l}\text { - Structured } \\
\text { overview of } \\
\text { information flows } \\
\text { and processes in } \\
\text { design and } \\
\text { provision of PSS as } \\
\text { a starting point for } \\
\text { adaptations }\end{array}$ \\
\hline $\begin{array}{l}\text { Designate a PSS } \\
\text { Facilitator to } \\
\text { coordinate } \\
\text { integration- } \\
\text { activities within } \\
\text { the company }\end{array}$ & $\begin{array}{l}\text { Early on in } \\
\text { product-service } \\
\text { integration or } \\
\text { when a lacking } \\
\text { integrational } \\
\text { collaboration } \\
\text { throughout the } \\
\text { lifecycle is } \\
\text { identified }\end{array}$ & $\begin{array}{l}\text { - Regular meetings including the } \\
\text { relevant departments (e.g. } \\
\text { product- and service-design, sales } \\
\text { and marketing, remanufacturing) } \\
\text { - Coordination of design efforts, } \\
\text { particularly in a temporal sense: } \\
\text { Focus on synchronous product- } \\
\text { service design }\end{array}$ & $\begin{array}{l}\text { - Better } \\
\text { communication } \\
\text { and understanding } \\
\text { among previously } \\
\text { separate company } \\
\text { parts } \\
\text { - Continuous } \\
\text { conversion of } \\
\text { involved } \\
\text { departments }\end{array}$ \\
\hline
\end{tabular}




\begin{tabular}{|c|c|c|c|}
\hline $\begin{array}{l}\text { What? (Course } \\
\text { of action) }\end{array}$ & $\begin{array}{l}\text { When? (What } \\
\text { level of PSS } \\
\text { maturity) }\end{array}$ & $\begin{array}{c}\text { How? (Approach, supporting } \\
\text { tools) }\end{array}$ & $\begin{array}{l}\text { Expected } \\
\text { outcome }\end{array}$ \\
\hline & & & $\begin{array}{l}\text { - Increased } \\
\text { efficiency in design } \\
\text { and provision }\end{array}$ \\
\hline $\begin{array}{l}\text { Evaluate a PSS } \\
\text { design method, } \\
\text { possibly partial } \\
\text { implementation } \\
\text { or process } \\
\text { adaptation }\end{array}$ & $\begin{array}{l}\text { At any time } \\
\text { when a lacking } \\
\text { communication/ } \\
\text { understanding } \\
\text { is identified, } \\
\text { particularly } \\
\text { between } \\
\text { product- and } \\
\text { service-design } \\
\text { departments }\end{array}$ & $\begin{array}{l}\text { - External support (consulting, } \\
\text { researchers) or internal PSS } \\
\text { facilitator coordinates efforts } \\
\text { - Assessment of current } \\
\text { procedures is key to understand } \\
\text { needed changes and to adapt an } \\
\text { existing method or to derive a } \\
\text { new one } \\
\text { - Integrative workshops with } \\
\text { representatives from all } \\
\text { concerned departments }\end{array}$ & $\begin{array}{l}\text { - Adjustments to } \\
\text { current procedures } \\
\text { and approaches } \\
\text { that support more } \\
\text { effective and } \\
\text { efficient PSS design } \\
\text { - Implementation } \\
\text { of method modules } \\
\text { or parts that fit the } \\
\text { current approach } \\
\text { - NOT a PSS design } \\
\text { method } \\
\text { implemented as is } \\
\text { (low compliance } \\
\text { and understanding } \\
\text { is to be expected) }\end{array}$ \\
\hline $\begin{array}{l}\text { Develop a } \\
\text { systematic } \\
\text { understanding } \\
\text { for life-cycle } \\
\text { cost and value } \\
\text { generation of } \\
\text { PSS offerings }\end{array}$ & $\begin{array}{l}\text { At a point in } \\
\text { time when such } \\
\text { an overview and } \\
\text { understanding } \\
\text { is lacking }\end{array}$ & $\begin{array}{l}\text { - Life-cycle costing of an existing } \\
\text { offering to have a base-line } \\
\text { understanding from a provider } \\
\text { perspective (e.g. supported by a } \\
\text { systematic tool: Sakao and } \\
\text { Lindahl, 2015) } \\
\text { - A Total Cost of Ownership (TCO) } \\
\text { approach can be considered if a } \\
\text { stronger focus on customer cost is } \\
\text { desired (Bonetti, Perona, and } \\
\text { Saccani 2016) } \\
\text { - Understand key value for } \\
\text { customer as well as for own } \\
\text { company with a lifecycle focus, e.g. } \\
\text { through meetings and discussions } \\
\text { with colleagues throughout the } \\
\text { lifecycle (designers, managers, } \\
\text { sales and service personnel, } \\
\text { remanufacturing; for an example } \\
\text { from the ICT industry see } \\
\text { Matschewsky et al., 2016) } \\
\text { - Assess and enhance value } \\
\text { capturing and creation in future } \\
\text { offerings (e.g. supported by an } \\
\text { evaluation approach: } \\
\text { Matschewsky et al., 2015) }\end{array}$ & $\begin{array}{l}\text { - Better } \\
\text { understanding for } \\
\text { the actual cost of } \\
\text { activities and } \\
\text { components } \\
\text { throughout the life } \\
\text { of a PSS and the } \\
\text { value created or } \\
\text { captured through } \\
\text { these } \\
\text { - An established } \\
\text { baseline for future } \\
\text { adjustments and } \\
\text { founded and } \\
\text { quantifiable } \\
\text { arguments for } \\
\text { change }\end{array}$ \\
\hline
\end{tabular}

\subsection{Implications for Future Research}

Undoubtedly, the implementation of the courses of action detailed above is, in 
itself, a challenge for industrial companies. Although some support systems with respect to these approaches are available, it is a substantial task for academia to provide further support for practitioners to more efficiently offer PSS. Following, trajectories for research are outlined and structured based on the outcomes of this study.

The importance of prescriptive PSS design methods and approaches supporting PSS design, if only as an aid to understanding the business model and its implications and to uncovering and addressing the individual pitfalls of servitisation, has been highlighted as a result of the work with the case companies. Nonetheless, improving academically designed methods for implementation and use in the industry remains an ongoing research task (Matschewsky, Lindahl, and Sakao 2015; Clayton, Backhouse, and Dani 2012; Vezzoli et al. 2015).

Information, feedback and data processing may be key to successfully design and provide PSS in the future (Opresnik and Taisch 2015). This factor in particular currently poses a substantial challenge for the case companies, as both Levor and Navitas are rushing to gather data, but they lack knowledge as to how to utilize it to capture and create more value.

Understanding changing incentives, lifecycle- instead of first-cost, and value-creation through services appears to still be a substantial task for companies today. Research in these fields is progressing (Sakao and Lindahl 2015; Bertoni et al. 2016; Vezzoli et al. 2015), advances in these areas and particularly their integration may be critical for the continued success of servitisation in industrial companies. In addition, all these issues concern the entire company management, and therefore management's decisions substantially influence the (nonJimplementation of integrated PSS. To advance the knowledge about PSS, it is of interest to continue investigating PSS' benefits (Matschewsky et al. 2016) and risks (Sakao, Öhrwall Rönnbäck, and Ölundh Sandström 2013) for the whole company.

Last but not least, extending the research towards a more detailed and quantitative description of a larger number of companies with regard to implemented solutions and performances concerning PSS is also a possible direction, as done with regard to the implementation of information and communication technologies (Belvedere, Grando, and Bielli 2013). This article has laid the foundation to carry out such research and can be used effectively to achieve this.

\section{Conclusions}

In order to provide a cutting-edge understanding of the servitisation process within industrial companies for both academia and industrial practice, this article has addressed challenges in the design and provision of PSS in two industrial companies, as well as opportunities inherent to these challenges and solutions available to overcome them.

The challenges identified around the design and provision of PSS are related to a persistent product-centred mindset as well as the organisational separation of product- and service design. Further, the misalignment of current design- and provision-processes with the changing incentive structures for PSS emerged as a substantial hindrance. Lastly, the ever-increasing importance of data and information as well as an effective understanding of cost in PSS were a challenge. 
A number of efforts have been identified and characterised as possible solutions to these challenges. Prescriptive approaches and methods played a key role, not only in providing direct solutions or ways forward in response to challenges, but also by triggering activity within the case companies. This led to the development and implementation of additional, internally driven approaches. The appointment of a management-position PSS Facilitator with the task to align and gradually integrate product and service design was such an effort initiated by case company Navitas. Arriving at this solution was aided by a prescriptive approach the testing and adaptation of a PSS design method. The PSS design method was crucial in identifying and but also combating servitisation challenges. It supported the case company by creating an understanding of important PSS design issues and providing practitioners with a communication structure to bridge the gap between previously separate company departments, both spatially and temporally.

Understanding the status quo of PSS design and provision through actor mapping proved to be another useful and easily implementable approach. Finally, lifecycle costing as well as provider- and customer value-assessment were found to be useful prescriptive methods to describe and illustrate the changes in incentive structure due to servitisation and to distil knowledge from data. They can also serve as a basis for providing efficient PSS with a balanced customer- and provider-focus.

To ensure that these solutions, whether prescriptive or individual in nature, are relevant to as many actors in industrial practice as possible, information about the servitisation-process of the case-companies has been provided and the findings have been discussed in light of prior research.

This research was conducted with the main aim of supporting industry actors in their servitisation. Both Levor and Navitas are successful in their endeavours as industrial companies and providers of PSS. As underlined in relation to prior research, the challenges they have experienced in this transition are not unique and likely apply to other industrial actors as well. The same may be true for the action the case companies have taken to overcome these challenges, or better yet, to draw benefit from them. As a result, by adapting these courses of action to their particular circumstances, other industrial actors may be able to facilitate their own process of bringing PSS to market in a more efficient and effective fashion.

\section{Acknowledgements}

The authors wish to thank both case companies Levor and Navitas, which funded this research individually. The work was also supported in part by the Mistra REES (Resource Efficient and Effective Solutions) program, funded by Mistra (The Swedish Foundation for Strategic Environmental Research, No. 2014/16) as well as the program for Strategic Innovation, funded by Vinnova (Swedish Governmental Agency for Innovation Systems). Our gratitude of course belongs to the many practitioners who participated in this research through dedicating their time, sharing their knowledge and experience and allowing us to get a deep understanding for the transition to PSS in industrial companies.

\section{References}

Akasaka, Fumiya, Yutaro Nemoto, Koji Kimita, and Yoshiki Shimomura. 2012. 
"Development of a Knowledge-Based Design Support System for ProductService Systems." Computers in Industry 63 (4): 309-318.

Baines, Tim S., Ali Z. Bigdeli, Oscar F. Bustinza, Victor Guang Shi, James Baldwin, and Kieth Ridgway. 2017. "Servitization: Revisiting the State-of-the-Art and Research Priorities." International Journal of Operations and Production Management 37 (2): 256-278.

Baines, Tim S., H W Lightfoot, and J M Kay. 2009. "Servitized Manufacture: Practical Challenges of Delivering Integrated Products and Services." Proceedings of the Institution of Mechanical Engineers, Part B: Journal of Engineering Manufacture 223 (9). SAGE Publications: 1207-1215.

Belvedere, Valeria, Alberto Grando, and Paola Bielli. 2013. “A Quantitative Investigation of the Role of Information and Communication Technologies in the Implementation of a Product-Service System." International Journal of Production Research 51 (2). Taylor \& Francis Group: 410-426.

Bertoni, Alessandro, Marco Bertoni, Massimo Panarotto, Christian Johansson, and Tobias C. Larsson. 2016. "Value-Driven Product Service Systems Development: Methods and Industrial Applications." CIRP Journal of Manufacturing Science and Technology 15: 42-55.

Blessing, Lucienne T.M., and Amaresh Chakrabarti. 2009. DRM, a Design Research Methodology. London: Springer London.

Brax, Saara. 2005. "A Manufacturer Becoming Service Provider - Challenges and a Paradox." Managing Service Quality: An International Journal 15 (2). Emerald Group Publishing Limited: 142-155.

Cavalieri, Sergio, and Giuditta Pezzotta. 2012. "Product-Service Systems Engineering: State of the Art and Research Challenges." Computers in Industry 63 (4): 278-288.

Ceschin, Fabrizio. 2013. "Critical Factors for Implementing and Diffusing Sustainable Product-Service Systems: Insights from Innovation Studies and Companies' Experiences." Journal of Cleaner Production 45: 74-88.

Clayton, Richard J., Chris J. Backhouse, and Samir Dani. 2012. "Evaluating Existing Approaches to Product-service System Design." Journal of Manufacturing Technology Management 23 (3). Emerald Group Publishing Limited: 272-298.

Dachs, Bernhard, Sabine Biege, Martin Borowiecki, Gunter Lay, Angela Jäger, and Doris Schartinger. 2014. "Servitisation of European Manufacturing: Evidence from a Large Scale Database." The Service Industries Journal 34 (1). Routledge: 5-23.

Datta, Partha P., and Rajkumar Roy. 2010. "Cost Modelling Techniques for Availability Type Service Support Contracts: A Literature Review and Empirical Study." CIRP Journal of Manufacturing Science and Technology 3 (2): 142-157. 
Desai, Avni, Mattias Lindahl, and Maria Widgren. 2016. "Actors and System Maps A Methodology for Developing Product/Service Systems.” In Sustainability through Innovation in Product Life Cycle Design, edited by Mitsutaka Matsumoto, Keijiro Masui, Sinnichi Fukushige, and Shinsuke Kondo. Springer Singapore.

Durugbo, Christopher. 2013. "Competitive Product-Service Systems: Lessons from a Multicase Study." International Journal of Production Research 51 (19). Taylor \& Francis: 5671-5682.

Eisenhardt, K. M. 1989. "Building Theories from Case Study Research.” Academy of Management Review 14 (4). Academy of Management: 532-550.

Elfving, S. W., and N. Urquhart. 2013. "Product Service System Challenges within Telecommunication: Reaching the Era of Mutual Dependency." In The Philosopher's Stone for Sustainability, 269-274. Berlin, Heidelberg: Springer Berlin Heidelberg.

Flick, Uwe. 2009. An Introduction to Qualitative Research. London, UK: SAGE Publications.

Gebauer, Heiko, Thomas Friedli, and Elgar Fleisch. 2006. "Success Factors for Achieving High Service Revenues in Manufacturing Companies." Benchmarking: An International Journal 13 (3). Emerald Group Publishing Limited: 374-386.

Glaser, Barney G., and Anselm L. Strauss. 2009. The Discovery of Grounded Theory: Strategies for Qualitative Research.

Goedkoop, Mark J, Cees J G Van Halen, Harry R M Te Riele, and Peter J M Rommens. 1999. "Product Service Systems, Ecological and Economic Basics." Economic Affairs 36 (March). VROM: 132.

Grönroos, Christian, and Päivi Voima. 2013. "Critical Service Logic: Making Sense of Value Creation and Co-Creation." Journal of the Academy of Marketing Science 41 (2): 133-150.

Isaksson, Ola, Tobias C. Larsson, and Anna Ohrwall Rönnbäck. 2009. “Development of Product-Service Systems: Challenges and Opportunities for the Manufacturing Firm." Journal of Engineering Design 20 (4). Taylor \& Francis: 329-348.

Krueger, Richard A., and Mary Anne Casey. 2014. Focus Groups: A Practical Guide for Applied Research. 5thed. Thousand Oaks: Sage Publications.

Kurak, Caio Di Francisco, Ana Paula B. Barquet, Henrique Rozenfeld, São Carlos, and São Paulo. 2013. "Challenges for PSS Implementation : Identification and Classification." Product-Service Integration for Sustainable Solutions. Springer Berlin Heidelberg, 275-285.

Lim, Chie-Hyeon, Kwang-Jae Kim, Yoo-Suk Hong, and Kwangtae Park. 2012. "PSS 
Board: A Structured Tool for Product-service System Process Visualization." Journal of Cleaner Production 37 (December): 42-53.

Lindahl, Mattias, Tomohiko Sakao, and Emma Carlsson. 2014. "Actors and System Maps for Integrated Product Service Offerings - Practical Experience from Two Companies." Procedia CIRP 16: 320-325.

Lindahl, Mattias, Erik Sundin, and Tomohiko Sakao. 2014. "Environmental and Economic Benefits of Integrated Product Service Offerings Quantified with Real Business Cases." Journal of Cleaner Production 64 (February). Elsevier Ltd: 288-296.

Manzini, E., and C. Vezzoli. 2003. "A Strategic Design Approach to Develop Sustainable Product Service Systems: Examples Taken from the 'environmentally Friendly Innovation' Italian Prize." Journal of Cleaner Production 11 (8): 851-857.

Martinez, Veronica, Marko Bastl, Jennifer Kingston, and Stephen Evans. 2010. "Challenges in Transforming Manufacturing Organisations into ProductService Providers." Edited by M. Leseure. Journal of Manufacturing Technology Management 21 (4). Emerald Group Publishing Limited: 449-469.

Matschewsky, Johannes. 2017. "PSS without PSS Design - Possible Causes, Effects and Solutions." In Sustainability through Innovation in Product Life Cycle Design, 233-248. Springer Japan.

Matschewsky, Johannes, Mattias Lindahl, and Tomohiko Sakao. 2015. "Facilitating Industrial Adoption of Design Methods for Product-Service Systems." In ICED15: 20th International Conference on Engineering Design, 301-310. Milan.

Matschewsky, Johannes, Tomohiko Sakao, Saeed Khanagha, and Sofi W. Elfving. 2016. "What's in It for the Provider? The Case of a Telecom Vendor's Value Capturing from the Transition to Product-Service Systems." Procedia CIRP 47: 6-11.

Matschewsky, Johannes, Tomohiko Sakao, and Mattias Lindahl. 2015. "ProVa Provider Value Evaluation for Integrated Product Service Offerings.” Procedia CIRP 30: 305-310.

Maussang, Nicolas, Peggy Zwolinski, and Daniel Brissaud. 2009. "Product-Service System Design Methodology: From the PSS Architecture Design to the Products Specifications." Journal of Engineering Design 20 (4). Taylor \& Francis: $349-366$.

Meier, H., R. Roy, and G. Seliger. 2010. “Industrial Product-Service Systems-IPS2.” CIRP Annals - Manufacturing Technology 59 (2): 607-627.

Miles, MB, AM Huberman, and J Saldaña. 2013. Qualitative Data Analysis: A Methods Sourcebook. SAGE Publications.

Mont, Oksana. 2002. "Drivers and Barriers for Shifting towards More Service- 
Oriented Businesses: Analysis of the PSS Field and Contributions from Sweden." The Journal of Sustainable Product Design 2 (3/4): 89-103.

Morelli, Nicola. 2006. "Developing New Product Service Systems (PSS):

Methodologies and Operational Tools." Journal of Cleaner Production 14 (17): 1495-1501.

O’Brien, Christopher. 2013. "Fifty Years of Shifting Paradigms." International Journal of Production Research 51 (23-24). Taylor \& Francis: 6740-6745.

OECD. 2015. OECD Green Growth Studies: Material Resources, Productivity and the Environment. OECD Publishing.

Oliva, Rogelio, and Robert Kallenberg. 2003. "Managing the Transition from Products to Services." International Journal of Service Industry Management 14 (2): 160-172.

Opresnik, David, and Marco Taisch. 2015. "The Value of Big Data in Servitization.” International Journal of Production Economics 165: 174-184.

Patton, Michael Quinn. 2002. Qualitative Research \& Evaluation Methods. SAGE Publications.

Pezzotta, Giuditta, Roberto Pinto, Fabiana Pirola, and Mohamed-Zied Ouertani. 2014. "Balancing Product-Service Provider's Performance and Customer's Value: The SErvice Engineering Methodology (SEEM)." Procedia CIRP 16: 5055.

Pezzotta, Giuditta, Fabiana Pirola, Alice Rondini, Roberto Pinto, and Mohamed-Zied Ouertani. 2016. "Towards a Methodology to Engineer Industrial ProductService System - Evidence from Power and Automation Industry." CIRP Journal of Manufacturing Science and Technology.

Pigosso, Daniela C A, and Tim C. McAloone. 2016. "Maturity-Based Approach for the Development of Environmentally Sustainable Product/service-Systems." CIRP Journal of Manufacturing Science and Technology 15: 33-41.

Rebitzer, Gerald, and David Hunkeler. 2003. "Life Cycle Costing in LCM: Ambitions, Opportunities, and Limitations." The International Journal of Life Cycle Assessment 8 (5). Ecomed: 253-256.

Sakao, Tomohiko, Herbert Birkhofer, Veselin Panshef, and Edgar Dörsam. 2009. "An Effective and Efficient Method to Design Services: Empirical Study for Services by an Investment-Machine Manufacturer." International Journal of Internet Manufacturing and Services 2 (1). Inderscience: 95-110.

Sakao, Tomohiko, and Mattias Lindahl. 2012. "A Value Based Evaluation Method for Product/Service System Using Design Information." CIRP Annals Manufacturing Technology 61 (1). CIRP: 51-54.

Sakao, Tomohiko, and Mattias Lindahl. 2015. “A Method to Improve Integrated 
Product Service Offerings Based on Life Cycle Costing." CIRP Annals Manufacturing Technology 64 (1): 33-36.

Sakao, Tomohiko, Anna Öhrwall Rönnbäck, and Gunilla Ölundh Sandström. 2013. "Uncovering Benefits and Risks of Integrated Product Service Offerings - Using a Case of Technology Encapsulation." Journal of Systems Science and Systems Engineering 22 (4): 421-439.

Settanni, Ettore, Nils E. Thenent, Linda B. Newnes, Glenn Parry, and Yee Mey Goh. 2015. "To Cost an Elephant: An Exploratory Survey on Cost Estimating Practice in the Light of Product-Service-Systems." Journal of Cost Analysis and Parametrics 8 (1). Taylor \& Francis: 1-22.

Song, Wenyan, Xinguo Ming, Yi Han, Zhitao Xu, and Zhenyong Wu. 2014. “An Integrative Framework for Innovation Management of Product-service System." International Journal of Production Research 53 (8). Taylor \& Francis: 2252-2268.

Strauss, Anselm, and Juliet M. Corbin. 1998. Basics of Qualitative Research:

Techniques and Procedures for Developing Grounded Theory. 2nded. Thousand Oaks.

Szwejczewski, Marek, Keith Goffin, and Zissis Anagnostopoulos. 2015. "Product Service Systems, after-Sales Service and New Product Development." International Journal of Production Research 53 (17). Taylor \& Francis: 53345353.

Tan, Adrian Ronald. 2010. "Service-Oriented Product Development Strategies." PhD Thesis. DTU Management.

Tukker, Arnold. 2015. "Product Services for a Resource-Efficient and Circular Economy - a Review.” Journal of Cleaner Production 97. Elsevier Ltd: 76-91.

Ulaga, Wolfgang, and Werner J Reinartz. 2011. "Hybrid Offerings : How Manufacturing Firms Combine Goods and Services Successfully." Journal of Marketing 75: 5-23.

Vasantha, Gokula, Rajkumar Roy, and Jonathan Corney. 2014. "Challenges and Opportunities in Transforming Laser System Industry to Deliver Integrated Product and Service Offers." In Collaborative Systems for Smart Networked Environments, 127-134. Springer Berlin Heidelberg.

Vasantha, Gokula Vijaykumar Annamalai, Rajkumar Roy, Alan Lelah, and Daniel Brissaud. 2012. "A Review of Product-Service Systems Design Methodologies." Journal of Engineering Design 23 (9): 635-659.

Vezzoli, Carlo, Fabrizio Ceschin, Jan Carel Diehl, and Cindy Kohtala. 2015. "New Design Challenges to Widely Implement 'Sustainable Product-Service Systems.'” Journal of Cleaner Production 97: 1-12.

Wang, P.P., X.G. Ming, D. Li, F.B. Kong, L. Wang, and Z.Y. Wu. 2011. “Status Review 
and Research Strategies on Product-Service Systems." International Journal of Production Research 49 (22). Taylor \& Francis Group: 6863-6883.

Windahl, Charlotta, and Nicolette Lakemond. 2006. "Developing Integrated Solutions: The Importance of Relationships within the Network." Industrial Marketing Management 35 (7): 806-818.

Yin, Robert K. 2013. Case Study Research: Design and Methods. SAGE Publications. 